九病虫研会報 $52: 66-70 （ 2006 ）$

Kyushu Pl. Prot. Res. $52 ： 66-70$ (2006)

\title{
沖縄県におけるカンキツグリーニング病保毒虫 発生の現状と分布状況
}

大石 毅 - 豊里 哲也・諸見里知絵 -玉城 秀和 -上問 君子・谷口 昌弘・河村 太 (沖縄県農業研究センター)

\begin{abstract}
Geographical distribution of the Asian citrus psyllid infected with Candidatus Liberibacter asiaticus in Okinawa Prefecture. Tsuyoshi Ooishi, Tetsuya Toyosato, Chie Moromizato, Hidekazu Tamashiro, Kimiko Uema, Masahiro Taniguchi, Futoshi Kawamura. (Okinawa Prefectural Agricultural Research Center, Makabe 820, Itoman. Okinawa 901-0336. Japan)
\end{abstract}

沖縄県内においてミカンキジラミ成虫（Diaphorina citri Kuwayama）を採集し,PCR検定によ りカンキツグリーニング病（以下：HLB）保毒虫の分布と発生状況を調査した。分布調査の結果, これまでHLBの発生が確認されていない南大東島と北大東島では保毒虫は検出されなかった。し かし, HLBの発生が確認されている沖縄島, 石垣島, 宮古島, 与那国島, 伊是名島および伊平屋 島では保毒虫が検出され，保毒虫率はゲッキッでは 0 ～21.0\%，カンキッ類では9.6〜48.4\%で あった。本病に罹病しないとされるゲッキッ上にも保毒虫が確認されたことから，ミカンキジラ ミ成虫はカンキツ類からゲッキッへと移動していることが示唆された。また2002年 2 月〜2004年 1 月にかけて $3 \sim 5$ ケ月ごとに行った定期調査の結果, 保毒虫の明確な季節的変動は確認されな かった。

Key words : Murraya exotica L., orange jasmine, transmission

\section{緒言}

ミカンキジラミ（Diaphorina citri Kuwayama）はカ ンキッグリーニング病 (Citrus huanglongbing, 以下 HLB) の病原体であるCandidatus Liberibacter asiaticus 媒介することから（Xu et al., 1988），本病が 分布するカンキッ栽培地域においてはもっとも重要な害 虫である。本種の寄主範囲はミカン科の植物に限られ, 各種栽培カンキツ類のほか, ゲッキッ Murraya exotica L.などが好適な寄主植物となっている (Aubert，1987)。 とくにゲッキッはHLBの発病は見られないが (Miyakawa，1980)，沖綶県内において生垣や路側带に 多く植栽され（高江洲, 2001 ; 河野，2001）, 開花期か ら結実期を除き新芽を形成するため，ミカンキジラミの 主要な発生源となっている。ミカンキジラミは国内にお いて奄美大島以南（屋富祖，2002）抢上び屋久島に分布 することが確認されている（井上，2004）。また, HLB は日本国内では1988年に沖縄県西表島で初めて発生が確 認され (Miyakawa and Tsuno, 1989), その後, 南北 大東島を除く沖縄県全域および鹿児島県の徳之島と喜界 島に分布を拡大した（河野ら，1997; 渡久地・河野,
1997 ; 内藤ら, 2001 ; 芦原, 2005)。HLB は病株からの 取木や接木，またはミカンキジラミにより媒介される。 特に, 近年の HLB 発生地域の搪大の大きな要因のひと つにミカンキジラミによる虫媒伝染が考えられている。 そのため, 今後の HLBの感染拡大防止において, 本種 の防除は重要である。しかし，HLB とミカンキジラミの 伝搬様式には不明な点が多く, 県内に扔ける HLB 保毒 虫に関する発生状況についての報告もない。

今回，カンキッ類とゲッキッに生息するミカンキジラ ミ成虫を採集し、PCR法により HLB保毒虫の分布および 発生状況について調查したので報告する。

なお，本研究の一部は（独）農業・生物系特定産業技 術研究機構運営費交付金プロジェクト研究 No. 166n「作 物及び家畜生産に㧍ける気候温暖化の影響評価とその制 御技術の開発」の助成により行われた。また，本文に入 るに先立ち，PCR 検定についてご指導をしてくださった 産業技術総合研究所（独）の深津武馬博士に厚く御礼申 し上げる。 


\section{材料および方法}

\section{1. 分布調查}

分布調查は2004年 4 月20日から28日にかけて, 沖縄島 北部, 伊平屋島, 伊是名島, 宮古島, 石垣島, 与那国島, 南大東島および北大東島にて行った。

\section{2. 定期調查}

定期調査は2002年11月から2004年 2 月にかけて，3 5 ヶ月招きに沖縄島北部，宮古島，石垣島，西表荀にて 行った。各島の調查地点は第 1 図に示した。

\section{3. 採集方法}

生垣や路側帯のゲッキッと園地または庭木のカンキッ 類（主にシークワーサーCitrus depressa L., タンカン Citrus tankan）に生息するミカンキジラミ成虫を捕虫 網（直径 $40 \mathrm{~cm}$ ) または吸虫管を用いて採集した。各島 それぞれ13〜21ヶ所について行った。採集個体は株 （4～58頭/株）ごとに, Fukatsu（1999）の方法に従い 保存液（アセトン）の入ったサンプル管（マルエム社 製：Type No. 3）に保存し，実験公に持ち㷌った。

\section{PCR 検定法}

PCR 検定は採集したすべての個体について行った。
DNA 抽出はマイクロチューブ（BIOplastics 社製：0.2 $\mathrm{m} l)$ にミカンキジラミ成虫 1 個体と $100 \mu l$ の抽出緩衝 液 $(0.01 \mathrm{M}$ Tris-HCl pH8.0,1 mM EDTA- $3 \mathrm{Na}$, $0.025 \mathrm{M} \mathrm{NaCl}, 5 \%$ プロテイナーゼK) を加え, 滅菌し た爪楊枝で磨砕し， $55^{\circ} \mathrm{C} 60$ 分， $94^{\circ} \mathrm{C} 15$ 分処理した後, 遠 心した上澄みを鋳型 DNA として用いた。PCR 反応液は， 鋳型 DNA $1 \mu l$ Kiti et al. (2000)の HLB 特異的プライ マー, GOINfwd ( 5 ' -GCGCGTATGCAATACGAGCGG CA- $3^{\prime}$ ) と GOrev ( $5^{\prime}$-GCCTCGCGACTTCGCAACC CAT- 3`) をそれぞれ $1 \mu l(10 \mathrm{pM})$, Ex Taq DNA Polymerase（夕カラバイオ社製）を $0.1 \mu l, \mathrm{dNTP}$ Mixture を1. $6 \mu l, 10 \times \mathrm{Ex} T a q$ Buffer $2 \mu l$ 加え, 精製水で全量を $20 \mu l$ とした。PCR 反応はサーマルサイ クラー(GeneAmp PCR System 9700, Applied Biosystems)

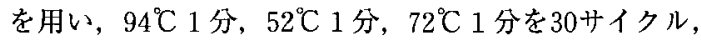
$70^{\circ} \mathrm{C} 10$ 分を 1 サイクル行った。得られた PCR 産物につ いて $1 \%$ アガーロースゲルを用いて電気泳動の後, 臭化 エチジウムで染色し増幅 DNA 産物を確認した。供試虫 が HLBを保毒しているならば, 約1100bp の増幅 DNA 産物（バンド）が得られる。このバンドの有無により， HLBの保毒を確認した。
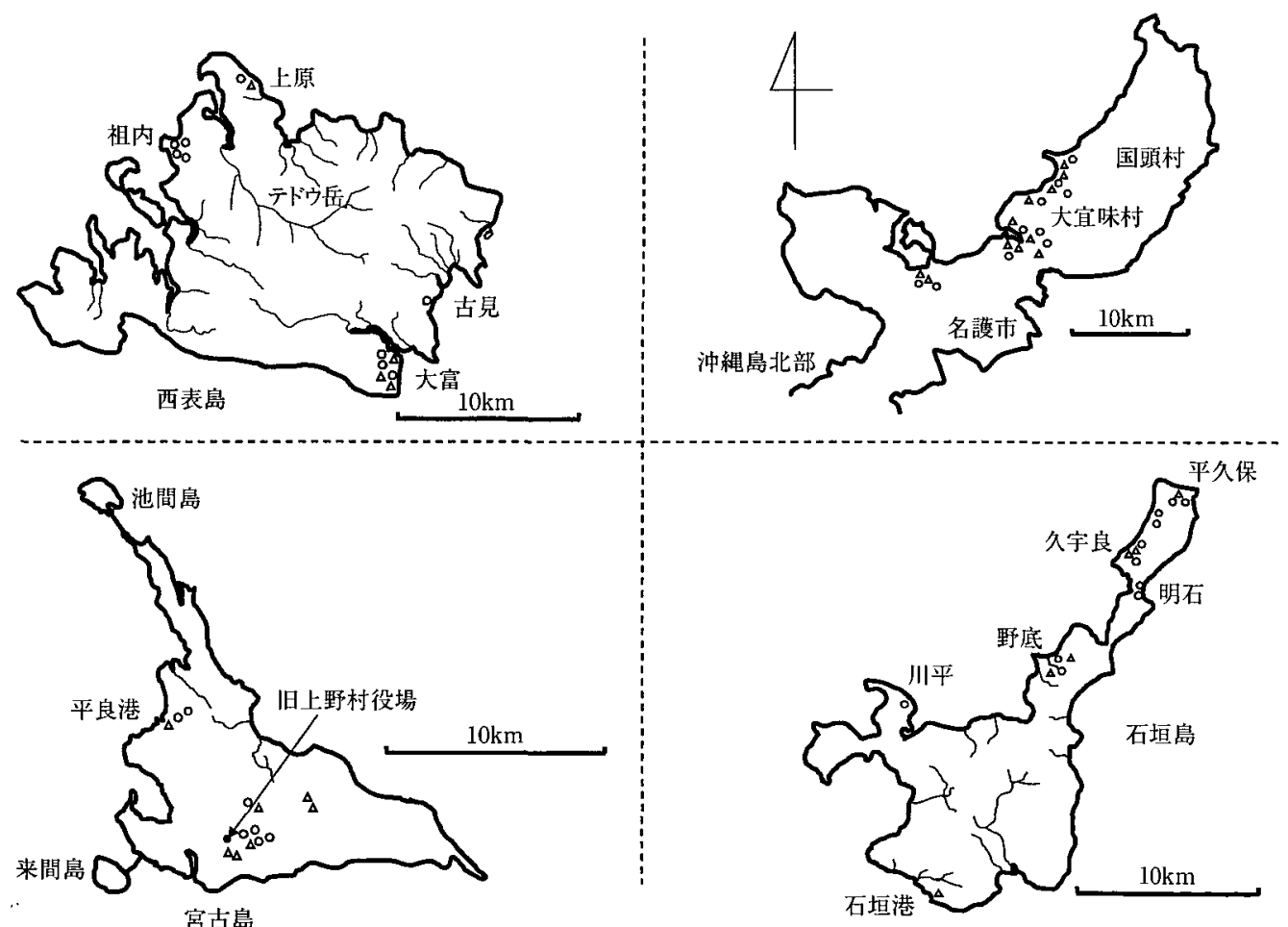

第 1 図 定期調查の調查地点

$\bigcirc$ : カンキツ類. $\triangle$ : ゲッキツ. 


\section{結果}

分布調查の結果を第 2 図に示した。HLBの発生が確認 されていない南北大東島を除くすべての調査地域におい て保毒虫が検出され，与那国島以外の調查地域において カンキツ類とゲッキッの両方から保毒虫が検出された。 保毒虫率はカンキツ類で9.6 48.4\%，ゲッキッでは 4.5 〜21.0\%であった。

定期調査の結果を第 1 ～表に示した。沖縄島北部の 保毒虫率は，ゲッキッで0.5〜 4.0\%，カンキッ類では $22.2 \sim 41.5 \%$ あった（第 1 表）。石坦島の保毒虫率は，

第 1 表 沖縄島北部のゲッキツおよびカンキッ類から 採集されたミカンキジラミ成虫の検定結果

\begin{tabular}{|c|c|c|c|c|c|}
\hline 寄主植物 & 調査年月 & 調查本数 & 検定虫数 & 陽性虫数 & $\underset{(\%)}{\text { 保毒虫率 }}$ \\
\hline \multirow{4}{*}{ ゲッキツ } & $2002 / 11$ & 7 & 193 & 1 & 0.5 \\
\hline & $2003 / 03$ & 10 & 130 & 4 & 3.1 \\
\hline & $2003 / 08$ & 8 & 209 & 1 & 0.5 \\
\hline & $2003 / 12$ & 16 & 100 & 4 & 4.0 \\
\hline \multirow{5}{*}{ カンキツ類 } & $2002 / 11$ & 15 & 297 & 109 & 36.7 \\
\hline & $2003 / 03$ & 9 & 180 & 40 & 22.2 \\
\hline & $2003 / 08$ & 7 & 125 & 28 & 22.4 \\
\hline & $2003 / 12$ & 18 & 272 & 113 & 41.5 \\
\hline & $2004 / 02$ & 2 & 62 & 23 & 37.1 \\
\hline
\end{tabular}

ゲッキッでは調查を開始した2002年12月から2003年10月 まで0.0〜1.1\%と保毒率は低かった。しかし，2004年 1 月には22. $2 \%$ に増加した（第 2 表）。カンキツ類では 0.0 〜 57.9\%であった（第 2 表)。西表島のゲッキッでは調 査を開始した2002年12月から2003年 8 月まで保毒虫は検 出されなかった。しかし，その後2003年10月と2004年 1 月には保毒虫が検出され，保毒虫率はそれぞれ $1.3 \%$ と $18.0 \%$ の值を示した (第 3 表)。また，カンキツ類では

第 2 表 石垣島のゲッキツおよびカンキツ類から採集 されたミカンキジラミ成虫の検定結果

\begin{tabular}{|c|c|c|c|c|c|}
\hline 寄主植物 & 調査年月 & 調査本数 & 検定虫数 & 陽性虫数 & $\begin{array}{c}\text { 保毒虫率 } \\
(\%)\end{array}$ \\
\hline \multirow{6}{*}{ ゲッキツ } & $2002 / 12$ & 5 & 167 & 0 & 0.0 \\
\hline & $2003 / 03$ & 8 & 111 & 1 & 0.9 \\
\hline & $2003 / 05$ & 3 & 30 & 0 & 0.0 \\
\hline & $2003 / 08$ & 6 & 183 & 2 & 1.1 \\
\hline & $2003 / 10$ & 6 & 83 & 0 & 0.0 \\
\hline & $2004 / 01$ & 6 & 72 & 16 & 22.2 \\
\hline \multirow{6}{*}{ カンキツ類 } & $2002 / 12$ & 2 & 27 & 1 & 3.7 \\
\hline & $2003 / 03$ & 2 & 20 & 0 & 0.0 \\
\hline & $2003 / 05$ & 6 & 98 & 28 & 28.6 \\
\hline & $2003 / 08$ & 13 & 18 & 1 & 5.6 \\
\hline & $2003 / 10$ & 13 & 57 & 11 & 19.3 \\
\hline & $2004 / 01$ & 6 & 38 & 22 & 57.9 \\
\hline
\end{tabular}
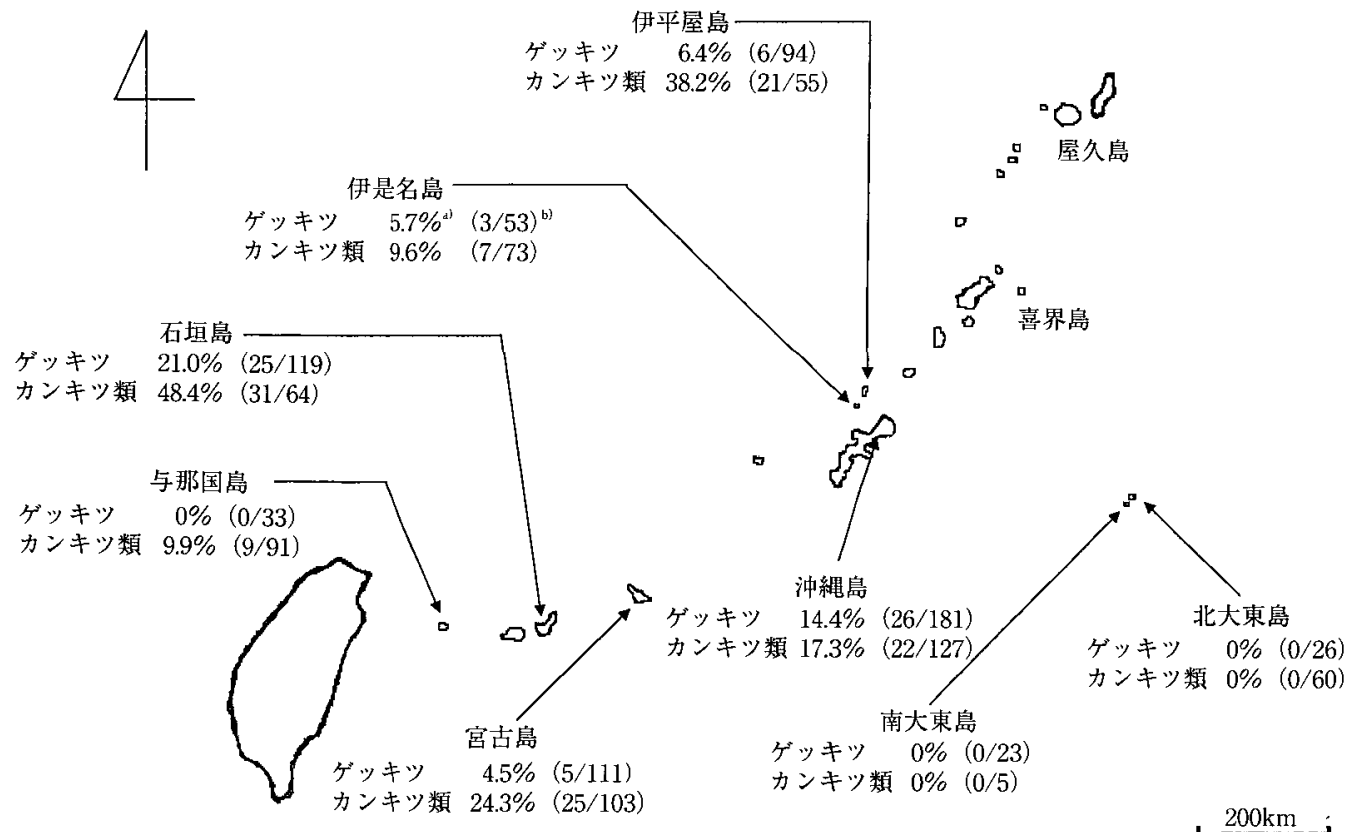

カンキツ類 $9.6 \% \quad(7 / 73)$

ンキツ類 $38.2 \%(21 / 55)$

第 2 図 沖縄島および周边離鳥における保毒虫の分布調查. a) 数値は保毒虫率. b) HLB 陽性個体 数 / 検定虫数. 
第3 表 西表島のゲッキッおよびカンキツ類から採集 されたミカンキジラミ成虫の検定結果

\begin{tabular}{|c|c|c|c|c|c|}
\hline 寄主植物 & 調查年月 & 調隹本数 & 検定虫数 & 陽性虫数 & $\begin{array}{c}\text { 保毒虫率 } \\
(\%)\end{array}$ \\
\hline \multirow{6}{*}{ ゲッキッ } & $2002 / 12$ & 2 & 42 & 0 & 0.0 \\
\hline & $2003 / 03$ & 6 & 60 & 0 & 0.0 \\
\hline & $2003 / 05$ & 5 & 35 & 0 & 0.0 \\
\hline & $2003 / 08$ & 3 & 119 & 0 & 0.0 \\
\hline & $2003 / 10$ & 3 & 75 & 1 & 1.3 \\
\hline & $2004 / 01$ & 2 & 50 & 9 & 18.0 \\
\hline \multirow{6}{*}{ カンキツ類 } & $2002 / 12$ & 2 & 26 & 0 & 0.0 \\
\hline & $2003 / 03$ & 5 & 67 & 4 & 5.9 \\
\hline & $2003 / 05$ & 2 & 17 & 0 & 0.0 \\
\hline & $2003 / 08$ & 4 & 14 & 0 & 0.0 \\
\hline & $2003 / 10$ & 3 & 10 & 0 & 0.0 \\
\hline & $2004 / 01$ & - a) & - & - & - \\
\hline
\end{tabular}

a) 採集個体なし.

2003年 3 月の保毒虫率は $5.9 \%$ あ゙あったが, 調查株が HLB 発病により枯死または伐採されたため，その後は カンキツ類からはミカンキジラミ成虫はほとんど採集さ れず，保毒虫も検出されなかった（第 3 表）。宮古島の 保毒虫率は，ゲッキッで0.0〜 20.4\% (第 4 表)，カンキ ツ類では3.1〜43.8\%であった（第 4 表）。今回の調查に おいては，保毒虫率の季節的な変動は確認できなかった。 いずれの調查に扔いてもゲッキッとカンキツ類の雨方 から保毒虫が検出されたが, 保毒虫率はカンキツ類に比 較してゲッキッでは低い值を示した。カンキツ類上でミ カンキジラミの卵扔よび幼虫が観察されることはまれで あった。今回の調查において, ミカンキジラミ成虫が採 集されたカンキツ類はすべて住宅地域の庭木または粗放 的に栽培されている園の木であり，薬剤防除が行われ， 管理の行きとどいた園地からはほとんど採集されなかっ た。

\section{考察}

今回の一連の調査でゲッキッ上に HLB 保毒虫が生息 することが初めて明らかとなった（第 $1 \sim 4$ 表，第 2 図)。このことは，ミカンキジラミ成虫がゲッキッとカ ンキツ類間を移動していることを示唆している。特に, 石垣島に扔いては, 周囲約 $300 \mathrm{~m}$ 以内にカンキツ類が存 在しないゲッキッ上で保毒虫が検出されたことから，ミ カンキジラミ成虫は少なくとも数百 $\mathrm{m}$ の距離を移動し てきた可能性がある。沖縄県北部のカンキツ栽培地域に おけるカンキツ類の保毒虫率の最大值は $41.5 \%$ であり (第 1 表), HLB 多発生地域であるインドネシアのカンキ
第 4 表 宮古島のゲッキッ拈よびカンキッ類から採集 されたミカンキジラミ成虫の検定結果

\begin{tabular}{cccccc}
\hline 寄主植物 & 調查年月 & 調查本数 & 検定虫数 & 陽性虫数保毒虫率 \\
$(\%)$
\end{tabular}

a) 採集個体なし.

ツ Citrus nobilis から採集されたミカンキジラミ成虫の 保毒虫率 $45.2 \%$ (Siti et al., 2000) と比較してもほとんど 差は無く, 極めて高い保毒虫率であった。

定期調查では，保毒虫率の季節的変動は明らかではな かった (第 $1 \sim 4$ 表)。その原因として調查日によって 採集したサンブル数にばらつきが大きいこと, 調查株が HLB 発症により枯死, 伐採されてしまったことなどが 考えられる。また，2004年 1 月は石垣島，西表島および 宮古島の保毒率は急激に增加した (第 $2 \sim 4$ 表)。この 要因として調查対象地域の HLBの感染が拡大し, それ に伴い保毒虫が增加した，もしくはこの時期の環境条件 がミカンキジラミの HLB 病原体の保毒に適していた, さらにはミカンキジラミの移動分散が頻繁に起こった, など様々なことが考えられる。保毒率は調查地域の HLBの発生状況やミカンキジラミ成虫の移動分散に大 きく影響を受けると考えられたことから，調查方法につ いて検討する必要があると思われる。

HLB 病原体の伝搬メカニズムは不明であるが，一般 的に虫媒性の篩部局在型の病原体は媒介虫の体内で増殖 し，唾液腺へ移行することによって伝搬される（福士ら， 1986)。PCR 法による検定は感度が高いため，HLB 感染 株の篩管液をミカンキジラミが吸汁することにより, 唾 液腺にHLBが無い場合でも腸内に HLB 病原体が残って いれば保毒虫として検出される。そのため, 今回検出さ れた保毒虫の中にもそのような状態のサンプルが多く含 まれていると考えられる。今後は唾液腺に HLB 病原体 を有する保毒虫の検定法, ミカンキジラミ体内に招ける HLB 病原体の移行や增殖機構は検討すべき重要な課題 
であると考えられる。

感染株の早期発見はHLBの感染拡大防止対策として 非常に重要である。そのため, 沖縄県においては HLB 感染樹の検定にスクラッチ法（澤岻ら，2006）やPCR 法 (Jagoueix et al., 1994) を用いることにより発病株の 検定を行っているが, 発症前にHLBの感染の有無を正 確に判定することは困難である。今後, HLB 保毒虫のモ ニタリングを実施することにより, HLB の発生未確認地 域では感染または発症前に感染拡大をより早く検知でき る可能性がある。また, HLB 発生地域において HLBの 保毒率は病株の伐採や薬剂散布後の防除効果を評価する 指標の一つとして有効であろう。

\section{引用 文 献}

芦原 亘（2005）カンキッグリーニンダ病と媒介昆虫ミ カンキジラミの分布掘大. 今月の農業 $49(1): 77$ 81.

Aubert. B. (1987) Trioza erytreae Del Guercio and Diaphorina citri Kuwayama (Homoptera:Psylloidea) the two vectors of citrus greening disease : biological aspects and possible control strategies. Fruits 42 : 149-162.

Fukatsu. T. (1999) Acetone preservation: a practical technique for molecular analysis. Mol. Ecol. $8: 1935$ 1945.

福士貞吉・鈴木直治・四方英四郎（1986）植物のウイル 又病. 盖賢堂 (東京), pp. 514 .

井上広光 (2004) キジラミ類の分類と生態 (2). 植物 防疫 $58: 29-32$.

Jagoueix, S., J-M. Bove and M. Garnier (1994) The phloem-limited bacterium of greening disease of citrus is a member of the $a$ subdivision of the Proteobacteria. J. Int. Syst. Bacteriol. 44 : 379-386. 河野伸二・蘇 鴻基・上原勝江（1997）沖縄本島に扩け るカンキッグリーニング病の初発生. 日植病報 63 ：
256.

河野勝行（2001）わが国におけるカンキッグリーニング

病。農業㧍よび園芸 $76: 855-863$.

Miyakawa. T. (1980) Experimentally-induced symptoms and host range of citrus likubin (greening disease) . Ann. Phytopath. Soc. Jpn. $46: 224-230$.

Miyakawa, T and K.Tsuno (1989) Occurrence of citrus greening disease in the southern islands of Japan. Ann.Phytopath.Soc.Jpn. 55:667-670.

内藤 孝・田場 聡・豊里哲也・河野伸二・高江洲和 子・上原勝江（2001）カンキッグリーニング病の PCR による検定法と沖縄地域に求ける発生分布. 沖 綶県農業試験場研究報告 $23: 74-81$.

Siti, S., N. Nikoh. S. Tsuyumu, S. Somowiyarjo and T. Fukatsu (2000) Complex endosymbiotic microbiota of the citrus psyllid Diaphorina citri (Homoptera: Psylloidea). Zoo. Sci. 17 : 983-989.

高江洲和子（2001）沖縄県におけるカンキッグリーニン グ病の発生状況. 今月の農業 $45(7): 76-80$.

澤岻哲也・豊里哲也・河野伸二 - 田場 聡 - 田場奏美 大城 篤・沼澤雅哉・渡慶次美歌（2006）スクラッチ 法によるカンキッグリーニング病の迅速簡易診断. 日 植病報（印刷中）。

渡久地章男・河野伸二（1997）沖縄県におけるカンキッ グリーニング病の発生状況および防除対策. 植物防疫 $51: 565-570$.

Xu, C. F. Y. H. Xia, K. B. Li and C. Ke, (1988) Further study of the transmission of citrus huanglongbing by a psyllid, Diaphorina citri Kuwayama. Pro. 10th Conf. IOCV (Riverside, CA) pp. 243-248.

屋富相昌子（2002）琉球列島産昆虫目録 増補改訂版 （東清二監修，屋富祖昌子・金城政勝・林 正美・小 濱継雄 - 佐々木健志 -木村正明 - 河村 太 編)。沖 縄生物学会 (西原), pp. 570 .

（2006年 4 月30日受領；8月14日受理） 